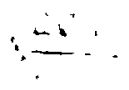

\title{
The Structure and Affinities of Peranema and Diacalpe.
}

\author{
BY \\ R. C. DAVIE, M.A., B.Sc. \\ Robert Donaldson Research Scholar of Glasgow University, Assistant in Botany in the \\ University of Edinburgh.
}

With Plates XXVIII and XXIX.

PERANEMA CYATHEOIDES, D. Don, was first collected in the mountains of Nepal, Sheopore, and Chandagiri by Wallich. It was included in his 'Plantae Asiaticae Rarae', and was sent in 1823 to the Honourable East India Company's Museum at the India House. Duplicates were most liberally distributed in May of the following year. One of these is in the Herbarium of the Royal Botanic Gardens at Kew. On this specimen, however, there is only a written label, bearing the name Sphaeropteris barbata, Wall. There is no description of the plant, not even a note of its marked characteristics. Wallich's description was not published until I830, when his 'Plantae Asiaticae Rarae' was issued. Meanwhile, David Don, in 1825, had published the 'Prodromus Florae Nepalensis' and had described Sphaeropteris, though in no great detail, under the name of Peranema cyathoides. Thus on the basis of priority of publication, as the label on Wallich's specimen is not printed but written, the name of the Fern must be kept as Peranema. Hooker and Baker in the 'Synopsis Filicum' give the specific name as Peranema cyatheoides, D. Don. This is also done by Christ in 'Die Farnkräuter der Erde', and by Christensen in the 'Index Filicum '. It is, however, more accurate to retain this specific name than to revert to Don's own 'cyathoides'.

It is included by Presl in his 'Tentamen Pteridographiae' (1836), where it is placed with Physematium, Kaulf., Thyrsopleris, Kze., and Cibotium, Kaulf., in the Peranemeae, the first tribe of the Hymenophoreae, Cohort I of the sub-order Cathetogyratae, Bernhardi. This tribe immediately follows the Cyatheaceae and precedes the Aspidiaceae. In 1842 it was included in J. Smith's 'Genera of Ferns' in Hooker's 'Journal of Botany ', vol. iv, p. 190. There it is placed in Section II of the Aspidieae,- the Orthophlebieae-a section characterized by their free venation, none of the

[A nnals of Botany, Vol. XXVI. No. CIL April, 1912.] 
venules anastomosing. It is separated from the Cyatheac (p. 181), 'because the pedicellate sori of Sphacropteris cannot in my opinion be viewed as an elevated receptacle'. Smith adds, 'On viewing their ${ }^{1}$ habit and characters in every other respect $I$ do not hesitate in placing them in this tribe' (Aspidieac). In Hooker's 'Species Filicum' $(1846)$ Peranema is again described under the name of Sphaeropteris, Wall., and is placed in the Woodsieae, the second sub-tribe of the Dicksonieae, Gaud. In $185^{6}$ it was described by Mettenius in his 'Filices Horti Botanici Lipsiensis ' and by him put, with Woodsia and Diacalpe, in the Aspidiaceae, Group IV of the Polypodiaceae. R. H. Beddome in the 'Ferns of Southern India' (1863) places it in the Polypodiaceae, in the group Peranemeae. It there follows the Davallieae, with Davallia and Microlepia, and immediately precedes the Cyatheae, with Cyathea and Alsophila. Robert Brown in I867 gave a full description of Peranema, placing it in his family Polypodiaceae. He remarks that it is clearly to be distinguished from several Cyatheae, but is closely related to Woodsia mexicana, R.Br. ' Hoc ultimo charactere et reticulatione involucri a Cyatheis nonnullis (involucro e medio venae orto) praesertim distinguenda; arctiori tamen affinitate nixa cum Woodsia, mediante specie mexicana ( $W$. mexicana, Nob.).' Hooker and Baker in the 'Synopsis Filicum' (1874) place it in their Dicksonieae. H. Christ in 'Die Farnkräuter der Erde' (1897) places it in the Aspidiaceae: And Diels in Engler and Prantl's 'Natürliche Pflanzenfamilien' includes it in the Woodsieae-Woodsiinae group of Polypodiaceae-the group which immediately succeeds the group Cyatheaceae.

From the differing positions in which the Fern has been placed it is evident that its systematic position is one of difficulty and debate. The prevailing tendency has been to relate it to the Woodsia group, a group included in the Polypodiaceae by most systematists, in the Dicksonieae by Hooker and Baker. In Wallich's account of the Fern ('Plantae Asiaticae Rarae', p. 42) he says of his own specimen sent to the East India Company's Museum: 'In the Museum just mentioned the Fern was labelled "Cyathea ? barbata, Wall. vix non genus novum, Sphaeropteris, Nob. non Bernhardi".' This confusion of Peranema with Cyathea by the Museum authorities is also suggested in David Don's description in the 'Prodromus Florae Nepalensis', where the following concluding observation is made: 'Obs. Genus a Cyathea, cui affine, omnino distinctum : indusiis sphaericis indivisis pedicellatis.' Robert Brown's remark, already quoted, confirms this suggestion of an affinity with the Cyatheaceae. On the other hand, Mettenius and Christ place it in the Aspidiaceae, while C. B. Clarke in the 'Review of the Ferns of Northern India ' ('Trans.Linn. Soc.', 2nd series, i, p. 435, 1880) describes Pcranema as difficult to separate, when without fruit, from Aspiditum spectabile, Wall. The intermediate position between 1 i. e. Diacalpe, Sthaeropleris, Woodsia, Hypoderris. 
the Cyatheaceac and the Aspidiaceae, adopted for it by Presl, Robert Brown, and Diels, will be confirmed in this account of its anatomy.

The observations here to be detailed, and those later to be detailed for Diacalpe aspidioides, Bl., have been made partly on Herbarium specimens, but especially upon material preserved in spirit and upon living specimens, which were supplied from India, through the kindness of the Director of the Calcutta Garden. Strong plants of Peraneina and Diacalpe from this source are under cultivation in the Glasgow Botanic Garden. The investigation was carried on partly in the Jodrell Laboratory, Royal Botanic Gardens, Kew. For facilities afforded there, I am much indebted to Lieut.Col. Prain, F.R.S. To Mr. L. A. Boodle, F.L.S., and to Professor F. O. Bower, F.R.S., under whose direction the work has been carried on, I am indebted for much help and criticism.

\section{External Characters.}

The stock is distinctly upright, some four to six inches in length. The roots spring from every side of it and are branched and fibrous. The leaves are from one to three feet in length and of a bright green colour. Their stalks are long, sometimes a foot in length, convex at first and then furrowed on the adaxial side. Both stock and rachis are covered with paleae, which are lanceolate, with acuminate tips; they have reticulate marking, almost entire or quite entire margins, and are of a light dusky red colour. These are persistent from the first on the young stalks. The leaves are tripinnate, broadly ovate, with acuminate apices. They have wide alternate pinnae, on the pinnules of which the leaf-segments are sessile. The leaf-segments are linear-oblong with rounded apices; the lower ones are pinnatifid, the upper are broadly crenate. On the main rachis and on that of the branches are short, subulate, hyaline, incurved hairs, on which small glands are borne. Similar glands are also found on the rachis among the hairs, but arising directly from the epidermal cells of the rachis. The venation is open and simple; no anastomosing veins are found in any part of the leaf (Pl. XXVIII, Fig. I). On the under side the veins are provided with little stalked glands, the stalks of which are sometimes unicellular, sometimes multicellular. The sori are produced superficially on the lower side of the leaf. Each sorus is borne on a short stalk and arises upon the surface of a vein, but always some distance from the tip of the vein. The indusium is entire except for a small pit which is present on the under side and quite close to the junction of the stalk with the indusium. At maturity a vertical split occurs across the sorus, and the two sides of the indusium become reflexed and finally flattened out. The sporangia are very crowded on the elongated receptacle and are long-stalked. Each has a pale dusky red annulus. The spores are sub-globose and covered with warty markings. 


\section{INTERNAL STRUCTURE.}

The stock is distinctly an upright one, widening gradually from the base upwards. It is covered by paleae of delicate texture and dark brown colour. Some of these are provided with numerous glands on the surface directed towards the stock. The whole stock is enveloped in a thick mass of sclerenchyma, several cell-layers in width. The ground parenchyma is compact, with few air spaces and those of small size, while the cells are filled with starchy and proteid contents. Throughout this parenchyma are scattered little masses of sclerenchyma, dispersed in irregular fashion, but of very firm texture. The leaves are inserted spirally on the stock, the divergence in the mature stock being one-seventh. A transverse section of the stock shows a series of meristeles, usually five or six in number, surrounded at their edges by a varying number of smaller strands (Fig. 2). One or two of the meristeles are elongated, and in transverse section show tracheides cut in an oblique or in a longitudinal direction. Other meristeles are rounded and have quite transversely-cut tracheides. If one of the elongated meristeles is followed up or down in the stock it is found to divide into two parts which assume a structure exactly like that of the remaining meristeles. Sometimes two elongated meristeles may be found opposite to each other. Generally, however, only one oval meristele appears in each section. This shows at once that the vascular system is dictyostelic. On dissection of the stock this dictyostele is found to consist of a series of strands united into a meshwork, in which the gaps have an oval form. It is indeed exactly like the advanced dictyostele generally exemplified in the vascular system of Nephrodium filix-mas, Rich. The gaps are found only opposite the entrance-points of leaf-traces into the dictyostele; there are no perforations.

The leaf-trace is itself made up of three main strands and four or five subsidiary ones. Two of the main strands occupy the adaxial corners of the petiole, while the third occupies a median position on the abaxial curved side. Two smaller strands are found between each adaxial main strand and the median one, while often still smaller strands, of the nature of commissures, may be found between these subsidiary strands or between them and the main strands (Fig. 3). Sometimes a commissural strand may be nipped off from one of the adaxial strands, pass up to the next subsidiary strand, fuse with it on one side, then pass off on the other side, to unite with the next subsidiary strand a little further up the petiole. This process is continued up the petiole, the commissural strand passing from one strand to the next until it arrives at the second adaxial strand of the petiole.

When the leaf-trace strands are followed from the petiole into the dictyostele they are found to insert themselves along the sides of the oval 
gap. The strands from any one leaf-trace are inserted on the lower half of the two limbs of vascular tissue enclosing the gap opposite the leaf, while the median main strand is inserted at the lower junction of these limbs (Fig. 4, I, II). All the bundles from any one leaf-trace are inserted on the Jower half of any leaf-gap. Evidently the upper half receives half the bundles from one leaf-trace which enters from a higher leaf and half the bundles from another. These two leaves are inserted on the axis obliquely above that of which the bundles enter on the lower half of the leaf-gap (Fig. 4, III).

This arrangement corresponds in the main with what occurs in the insertion of the leaf-trace on the dictyostele in Nephrodium filix-mas. But in the last-named Fern the adaxial bundles of the leaf-trace enter at the level of the bases of the gaps corresponding to the two leaves obliquely next above that to which the bundles belong. The median main strand enters at the fork on the lower half of the gap, just as in the case of Peranema cyatheoides (de Bary, 'Comp. Anat.', Fig. $13^{2}$, and description, p. 285).

Histologically the meristeles of the stock are uninteresting. The xylem is made up of regular tracheides, interspersed with few parenchymatous cells and with no definitely differentiated protoxylem.

This is a characteristic of the meristeles of the stock among the Cyatheaceae, and except in that respect calls for no comment. The first lignification of the undifferentiated parenchyma in the young stock is on the inner side, as is represented in Fig. 5, which is made from a transverse section just below the apex of the young shoot. The stele is thus technically endarch as regards sequence of development, though no specifically marked tracheides of protoxylem appear to be found. Each meristele is enclosed in an almost complete sheath of phloem, which extends round the xylem on the inner and outer sides of the bundle, but is interrupted at the corners, so that two lenticules of phloem are found, one on each side of the mass of tracheides. The phloem is in turn surrounded by a parenchymatous pericycle of several layers and an endodermis with thickened cell-walls, often enclosing brownish contents. At the corners of the bundle the xylem comes directly into contact with the pericycle.

In the petiole the strands differ in structure from those of the stock. The leaf-trace strands leave the meristeles of the stock in quite simple fashion. In the case of the median leaf-trace strand, which departs first from the dictyostele at the fork below the gap, the oval strand shows a little hump or swelling on its outer surface. This gradually increases in size and rounds itself off from the parent stele as a plate of xylem surrounded by a sheath of phloem. The adaxial leaf-trace bundles leave the corners of two of the meristeles. They are at first simple in structure with a xylem-plate surrounded by a phloem sheath. In no case does a strand of the leaf-trace leave any gap in the xylem of the meristele from which 
it springs. Soon after the adaxial strands have passed into the base of the petiole their inner edges become extended, so that ultimately each of these strands is curved in form, with a dilated abaxial portion and a delicate strip of xylem projecting sometimes almost parallel to the lower surface of this, and forming a hook, with its back towards the periphery of the petiole (Fig. 6,a). Two or three protoxylem groups are found in the positions prx. ${ }^{1}, p r x .{ }^{2}$, \&c. The whole of the hooked mass of xylem is surrounded by phloem, which, however, thins out or altogether disappears on the side of the mass facing the centre of the petiole. A several-layered pericycle and a single browncoloured layer of endodermis enclose each strand, while often a mass of sclerenchyma, one or two layers deep, encloses the whole bundle.

The median main bundle has a narrow plate of xylem with its long axis parallel to the adaxial side of the petiole, and with one or two protoxylem masses on the side facing the centre of the petiole. Phloem is present generally only on the side facing the periphery of the petiole. Sometimes a very small amount of phloem is developed also on the side facing the centre of the petiole.

The smaller subsidiary strands have the same structure.

Small groups of sclerenchymatous cells are here and there seen in the tissue of the petiole, generally between the subsidiary strands, but often also between them and the main strands. Other groups of sclerenchyma are found scattered in the ground tissue of the petiole.

When the supply to the pinnae is about to be given off, one of the adaxial strands of the petiole extends towards the adaxial corner of the petiole, lengthening the narrow strip of xylem on its adaxial side and pushing a tongue of xylem towards the pinna (Fig. 6,b). Some distance from the back of the hook two swellings occur in the xylem, one in the narrow portion, the other in the wide portion. These soon form a bridge, cutting off an island of parenchyma, the ring of xylem surrounding which has the shape of a signet ring in section, until at last the strand of the pinna-trace goes off as a ring of xylem with a larger amount of tracheides on one side than on the other (Fig. $6, c$ ). Then the wider side of the ring pushes up a tongue of xylem, a gap appears, filled with parenchyma, the two halves of the strand draw apart to right and left, leaving a channel of parenchyma between them (Fig. 7, III). These take on the shape of the adaxial strands of the petiole. From one of them is nipped off a median strand of the shape of the early pinna-trace. And from it and from the other prosrachial ${ }^{1}$ strand come two subsidiary strands. The final

1 As the faces of the rachis of the pinna are not orientated with regard to the stock but with regard to the rachis of the frond, the terms 'adaxial' and 'abaxinl' cannot be used in connexion with the pinna-trace strands. It is therefore necessary to use new terms whereby these strands may be distinguished from one another. 'Prosrachial' means directed towards the rachis ; 'aporachial ', directed away from the rachis. 
condition of the pinna-trace is that of a miniature petiole-trace, except that only two, instead of four or more, subsidiary strands are present. From the prosrachial strands the pinnules are supplied, as were the pinnae from the adaxial strands of the petiole (Fig. $7, \mathrm{IX}, \mathrm{X}$ ). Through the rachis of the frond from the departure of the first pair of pinnae to the departure of the second pair there run five vascular strands and a commissural strand. To the second pair of pinnae the supply is given off from the prosrachial bundles in the same fashion as to the first pair of pinnae. The same process is repeated for the third pair of pinnae. Between pair 3 and pair 4 the number of strands is reduced to three, with a commissural strand. And pair 4 (pinnae VII and VIII) are given off again in the normal manner. Beyond pair 4 the vascular strands are only three in number with occasional fusions of the median aporachial strand and one or other of the prosrachial strands. Towards the tip of the leaf the strands are reduced in number to two, the pinna-supply going off in the normal fashion. Ultimately only a single strand remains in the rachis. This strand has a narrow plate of xylem, with no incurved ends, and from its edges the simple strands to the ultimate segments are quite simply nipped off. Here the plate extends in the direction towards the pinna to be supplied, and the marginal group of tracheides surrounds itself with phloem, pericycle, and endodermis, while the parent strand re-forms its simple plate. As this type of pinna-supply differs from that given to the basal pinnae, it is proposed to term it the 'marginal' type, while that found in connexion with the lower pinnae and already described may be termed the 'extramarginal 'type. To these two types of pinna-supply and their significance reference will be made later on in the paper.

The root is diarch, with a single plate of xylem, composed of a set of four or six tracheides and two protoxylem groups, one at either end. The protoxylem elements abut directly on the pericycle, which is of two layers of cells at these points. Between the secondary xylem and the phloem is a series of parenchymatous cells, one or two layers thick. These have prominent nuclei and dense protoplasmic contents. Phloem surrounds this zone on the outer side. The endodermis has brownish cells, while the cortex is made up of thickened cells with deep brown coloured walls. The greater part of the piliferous layer breaks away, leaving the cortex as the outermost layer of the root. The stele comes off obliquely from the back of one of the meristeles of the stock, the root passing out into the soil in a slightly decurrent direction.

On the petiole and rachis of the mature leaf are innumerable paleae and hairs. The paleae are very similar to those on the stock, but their edges are quite entire. Each runs out into an acuminate apex (Fig. 8). Along the margins of a palea a few unicellular glands are inserted (cf. the paleae of Blechnum occidentale, Gardiner and Ito, '87), and these project 
directly out from the edges of the palea. Occasionally a gland may be found on the adaxial face of the palea, usually about its centre. Curious curved hairs are liberally distributed upon the surface of the petiole and rachis among the paleae. These hairs are inserted on distended boss-like cells of the epidermis. Each hair is made up of eight or ten cells of rectangular form. Two of these rise directly up from the boss-like cell, while the rest form a tapering series which bends over at its tip almost to touch the epidermis. At the top of the curved part two or three glands are inserted. These are of the unicellular type found on the paleae. Sometimes a gland may be inserted near the tip of the hair, but more usually a group is found on the curved portion of the hair (Fig. 9).

Here and there on rachis, petiole, and on the back of the veinlets of the pinnae and pinnules unicellular glands are also found simply inserted on the epidermal cells. In the young parts of the plant and on the petiole these glands have a hyaline margin, which appears to be filled with a clear fluid secreted by the gland (Fig. IO). Right over the top of this secretion passes a limiting membrane, which does not, however, appear to be cutinized, though it is continuous with the outer layer of the stalk of the gland. In the older parts of the plant and on the lower portion of the petiole the glands have no hyaline covering, but are limited externally by a thin cellwall, and contain a distinct nucleus and dense cytoplasm (Fig. I I). Apparently the secreted fluid disappears from the glands as they grow older. The glands closely resemble those found in the tissue of the petiole and stock of Nephrodium filix-mas (de Bary, pp. 89 and 220, and Schacht, '63). They give to the plant a very distinct odour, somewhat recalling that of Heracleum Spliondylium, and also bearing some resemblance to that of Lastrea Oreopleris. In the case of Peranema, however, the glands do not show the golden appearance of those in $L$. Oreopteris, but rather a pearly white appearance by reflected light, while they are quite translucent by transmitted light.

On the lower surface of the veinlets in the pinnules are found short recurved hairs bearing no glands. They project from the epidermis and give the suggestion of little bent pegs harging down from the pinnules. They are multicellular, but their cells are in a single series or row, and are some six or seven in number.

The segmentation of stem and leaf goes on in the usual fashion for Leptosporangiate Ferns. The wings of the leaf show the customary marginal series of cells (Fig. I2).

\section{SORUS AND SPORANGia.}

The mature sorus and sporangium have been described by Mettenius ('Filices Horti Bot. Lips.', I 856, No. 40), and by Wallich ('Plantae Asiat. Rar.', p. 42). Drawings of sorus and sporangium after F. Bauer appear in 
Engler and Prantl's 'Naturliche Pflanzenfamilien', where habit drawings of the sorus by Diels are also produced. In 'Phil. Trans. ', vol. cxcii, I899, p 57, Professor Bower has given a description of the sporangium from Herbarium material. F. Bauer's drawings in the 'Genera Filicum' and Professor Bower's drawing (loc. cit., Fig. 92) give representations of the sporangia. The sorus has never been adequately figured. Bauer's figures give no real idea of the nature of the receptacle, and, as Professor Bower remarks, 'suggest a regularity of orientation, which is not, however, to be recognized as constant in Herbarium specimens.'

The sorus is superficial in insertion and stalked. The stalk springs from one of the lateral veinlets on the under side of the pinna, and generally grows out for one millimetre or longer, vertically from the leaf. The sorus is spherical and, as Wallich remarks, ' about the size of a Coriander seed'. The youngest stages have, unfortunately, not been available. The material sent from Calcutta had upon it only mature or almost mature sori. And the living plant which accompanied this material, and which is now growing in the Botanic Gardens in Glasgow, has, during the two years it has been there, produced no sori. From the youngest sori available for examination it appears as though the indusium completely encloses the sorus. But at one point, close to the junction of the stalk with the indusium, a minute pore can be seen on the outside of the sorus. This forms a very narrow slit leading into the interior. Except at this pore, the indusium is quite entire, giving the outward impression of an unbroken covering for the sorus. It is essentially a cup, developed unequally on its two sides and contracted at its rim, which is turned inwards (cf. Fig. 15). When the sorus is mature a series of cells across the top breaks down, and an irregular crack is formed from one side of the sorus to the other. The two flaps of indusium thus formed bend back, exposing the sporangia within to the outer air. In this opened condition the resemblance to the sorus of Cyathea is remarkably close and convincing. It is this opened sorus which has been drawn by Bauer.

The indusium is made up of a single layer of cells, except just at the point of insertion on the receptacle, where it may be two layers in thickness. The cells are triangular or quadrangular in outline with triangular thickenings at their corners, giving the whole indusium a lacelike appearance. The receptacle is distinctly elongated, and occupies about one-half of the cavity covered in by the indusium. A series of tracheides runs into the receptacle from the stalk, and they then spread out in fan fashion just above the point of junction of receptacle and indusium (Fig. 13). This vascular supply passes right through the stalk of the sorus in a median direction, and merges into the vascular supply of the vein of the pinna.

On this elongated receptacle, which is distinctly of the Gradate type 
and strongly recalls the receptacle of the Cyatheaceae, are inserted some four hundred sporangia. Young and old sporangia are inserted promiscuously round the receptacle, a predominance of younger ones occurring towards the lower edges (Figs. I4 and I5). Young ones also occur at the apex of the receptacle among the stalks of quite mature sporangia (Fig. 14). The sorus is thus one distinctly of the mixed type, upon a receptacle characteristic of the Gradatae. The presence of younger sporangia towards the lower edges of the receptacle confirms the suggestion of the derivation of this sorus from one of a Gradate type.

There is no regularity of orientation among the sporangia in the sorus. Their annuli are arranged pointing in all directions when looked upon from above.

The sporangium itself is long-stalked, the stalk often taking a slightly curved form, the convex side of the curve being on the same side as the annulus (Fig. 16). Two or even three series of elongated cells are found contributing to the length of this stalk. In section the stalk consists of three cells symmetrically arranged about the centre, one rather larger than the other two (Fig. 17) as in Nephrodium. The capsule is rather elongated, much like the capsule of a typical Polypodiaceous Fern. The annulus consists of twelve to fourteen cells, indurated on the four sides, though, as usual, least strongly on the outer walls (Fig. I6). It passes right over the top of the capsule, and is continued always right back to the stalk as an unbroken and symmetrical series of typically indurated cells (Fig. 16). Frequently indurated walls are found in the cells past the stalk, though more commonly the induration stops in the one just at its centre. The series of cells of the annulus is, however, always continued past the stalk. As this stalk consists of three cells, they are arranged in a group of two on one side of the capsule, with the single one on the other side. The annulus is continued to one side of the single one, passing right across the tops of the cells in the other two (Fig. I8). It is thus slightly oblique in its insertion (Fig. I9).

The stomium consists of a series of wide cells, often seven in number, which continue and complete the hoop of the annulus round the sporangial head. Two of these cells are always strongly indurated, and are wider than the rest (Fig. 20). It is between these that the first break occurs, which allows the mechanism of the annulus to work and to secure the dispersal of the spores. The dehiscence of the sporangium takes place by a series of irregular cracks stretching across the sides of the capsule from the stomium.

The spores within each sporangium appear to number sixty-four. This number is characteristic rather of the Gradatae than of the Mixtae, though it is a feature to be anticipated in view of the elongated receptacle and the slight obliquity of the annulus. These three features of sorus and 
sporangium must be weighed against the long stalk of the sporangium and the mixed condition of the sorus in estimating the systematic position of Peranema. For the present it may be noticed that they all indicate that Peranema occupies an interesting position intermediate between Gradatae and Mixtae, and combines in its mechanism for spore production and dispersal the main characteristics of both groups.

The spores are very characteristic. They are of somewhat large size, and have on their surfaces very peculiar markings (Fig. 21). Each spore is surrounded by a membrane which encloses it rather loosely. At certain points, perhaps four or six or more, on its surface, the membrane is attached to the spore itself. These points take the form of little circular discs, each with a minute papilla in its centre, a portion of the membrane detached from the spore wall and filled with air. As a result of the presence of these circular pits and their included papillae, the surface of the membrane appears to be crossed by a series of folds of irregular shape. These are of course the portions of the membrane surrounding the circular pits, portions which are quite free from the spore. Such markings are found with some slight variation among many genera of Polypodiaceae, particularly in the genus Aspidiuin. They have lately been described by Hannig ('11). He finds that in the Cyatheaceae (loc. cit., p. 342), and in the genus Polypoditum (p. 344), there is no loose membrane ('perispore') around the spores. From the characteristic appearance of the perispore in the genus Aspidium he has been led to distinguish spores surrounded by a similar perispore as 'aspidioid'. He remarks (p. 340) that the genera Peranema, Diacalpe, and Woodsia possess aspidioid spores.

Unfortunately the first set of germinated spores in the Glasgow Botanic Gardens damped off before the antheridia had developed upon the prothalli, and the second set have not yet produced antheridia. The first stages of development are quite normal. The later stages have not been available, and no conclusions can therefore be made from the characters of the gametophyte generation.

DIACALPE ASPIDIOIDES, Bl, was first described by C. L. Blume in his 'Enumeratio Plantarum Javae et Insularum adjacentium', published in 1828. From the genus Woodsia, $\mathrm{R}$. Br., to which he says it bears close affinity, Blume separates it because the indusium is not 'dish-shaped and ciliated'. He places it in the third section of Kaulfuss's family Polypodiaceae, a section characterized by the sporangia being borne on receptacles, and by the indusium springing from below the sorus or being altogether absent. In the same section are included also Cyathea, Alsophila, and Hemitelia. Diacalpe grows, he remarks, 'in sylvis Javae altissimis'.

It is included in the Appendix to Presl's 'Tentamen Pteridographiae' (1836), with the query: 'An Cyatheacea, an Cathetogyrata stirps?' 
J. Smith, in Hooker's 'Journal of Botany', iv, 1842, p. I91, assigns it, with Peranema and Woodsia, to the Aspidieae.

By Sir W. J. Hooker ('Genera Filicum', t. 99, and 'Species Filicum'), it is placed beside Peranema in the Dicksonieae, sub-tribe Wondsieae.

In the 'Synopsis Filicum' (Hooker and Baker, '74), it appears next to Alsoplizila and between it and Matonia, accompanied by the comments (p. 45): 'This genus seems more appropriately placed with the Cyatheae than with the Dicksonieae. The fronds much resemble those of Davallia rodosa' (which is the original Acrophorus of Presl). The close resemblance between Diacalpe aspidioides and Davallia nodosa is mentioned also by C. B. Clarke in the 'Review of the Ferns of Northern India' ("Trans. Linn. Soc. ', and ser., vol. i, pp. 434 and 445).

Captain R. H. Beddome in 'The Ferns of Southern India' (1863) separates Peranema and Diacalpe as the group Peranemeae of the Polypodiaceae. This group comes between the Davallieae (including Microlepia and Davallia) and the Cyatheae (with Cyathea and Alsophila).

Raciborski ('98) in the 'Pteridophyten der Flora von Buitenzorg' places Diacalpe between Asplcnitum and Dicksonia in the B. II group of Polypodiaceae.

Diels (Engler and Prantl's 'Natürl. Pflanzenfam.') associates Diacalpe with Peranema, and these two with Woodsia, Hypoderris, and Acrophorus in the Woodsieae group of Polypodiaceae.

By Wallich, Diacalpe aspidioides was named Aspidium foliolosum (Cat. no. 359) and Sphaeropteris Hookeriana (Cat. no. 775). Following on this Presl, though he puts 'Diacalpe aspidioides, Bl.', among the insufficiently described genera, calls Aspidium foliolosum by the name Cystopteris gigantea, and places Cystopteris next to Acrophorus.

By Kunze ('Anal. Pterid.', p. 43) Diacalpe was named Physematium aspidioides. Another species of Physematium ( $P$. molle, Kaulf.) is called Woodsia mexicana by Robert Brown ('Miscellaneous Works', ii, p. 547), who remarks that it is closely related to Peranema cyatheoides. These confusions of nomenclature all converge on a grouping together of Peranema, Diacalpe, Woodsia, and Acrophoris.

The hint of a relationship between Diacalpe and the Aspidieae given directly by J. Smith, and by Wallich in the name Aspidium foliolosum, is confirmed by Christ in a review of Christensen's 'Index Filicum' (Hedwigia, 1908, xlvii, p. 145): 'Peranema, Diacalpe, Acrophorus einerseits, Woodsia und $C y$ stopteris andererseits, werden wohl schliesslich auch zu den Aspidieae (bei Lastrea) gezogen wcrden müssen.' 


\section{External Characters.}

The stock is upright, or at first creeping and becoming upright before more than twelve leaves have been produced. It is narrower than that of Peranema, and is not covered by a dense felt of paleae. The leaf-insertion depends on the size of the stock; in one case the divergence has been found to be a fifth, in other cases it is irregular.

The lcaves are large, from two to four feet long, with a long petiole, and are decompound and herbaceous. The lower part of the petiole is covered with broad, brown membranaceous scales. Similar but smaller scales appear together with hairs as little tufts at the axils of the primary pinnae on the younger branches. The frond is tripinnate, the primary pinnae often being nearly opposite. The rachis of the frond and that of the pinnae bear short scales and hairs of a single long series of cells. Long hair-like scales also appear on the upper surface of the leaf above the veins. Unicellular glands are found on the petiole and rachis among the scales and hairs, but no glands are present elsewhere on the leaves. On older leaves the scales and hairs disappear from the raches, which are then quite smooth.

The primary pinnae are lanceolate, the secondary pinnae being obtuse and oblong-cuneate; the lower pinnules are deeply pinnatifid and somewhat decurrent, so that the rachis of the ultimate pinna is generally winged. The venation is open; the veins are simply pinnate, and the veinlets are undivided, not reaching quite to the margins of the leaflets.

The sori are produced superficially on the under surface of the leaf, usually on the lower anterior veinlet of each segment, at a point below its termination. Usually there is only one sorus on each veinlet. The sorus is apparently sessile, but it is not strictly so, being seated on a slightly elevated point, from which the entire sorus can be freely removed without rupturing the base of the indusium or receptacle. The indusium is at first quite entire, completely enclosing the sorus. Its texture is very coriaceous. It ultimately breaks irregularly at the apex, and opens by two or more valves. The receptacle is short and is covered by a large number of sporangia, irregularly arranged within the sorus.

The sporangium is long-stalked, with a somewhat bulky capsule, and an annulus vertical in insertion but slightly twisting to one side as it crosses the capsule. The spores have warty superficial markings.

\section{INTERNAL STRUCTURE.}

The transverse section of the stock very closely resembles that of the stock of Peranema cyatheoides. The meristeles are inserted in the same fashion, and the leaf-traces bear the same relation to the main vascular system as do those of Peranema. The vascular system is in Diacalpe also 
an advanced dictyostele, but all the gaps are here, too, leaf-trace gaps. Schlumberger ('Flora', cii, N. F. 2, I 9 I I, P. 409) states that there are perforations in the dictyostele in Diacalpe aspidioides: 'Ausser den Blattliucken tritt wie bei den Cyatheaceen eine ganze Reihe von "Perforationen " auf.' In the stocks I have dissected I have been unable to discover the presence of any such perforations. In all respects the dictyostele of Diacalpe has been found to agree with those of Peranema cyatheoides and Nephrodizm filix-mas. The leaf-trace is made up of three main bundles and a varying number of subsidiary bundles, with occasional commissural bundles uniting one main bundle with the subsidiary ones or with one of the other main bundles. The strands of the leaf-trace are inserted on the lower half of each gap opposite the entrance of the petiole to which the trace belongs, and the median main bundle of the trace enters the dictyostele at the lower fork of the gap. With regard to the histology of the supply of the leaftrace from the dictyostele, the facts are the same for Diacalpe aspidioides as for Peranema. The adaxial main bundles of the leaf-trace have deeply incurved hooks on their adaxial faces. From the backs of these hooks the pinna-traces go off in the extramarginal fashion. The pinna-trace is at first a simple strand, but it soon breaks up, as in Peranema, into three strands. The pinnules are supplied from these on the extramarginal type. The ultimate pinna is supplied in marginal fashion from a dorsiventrallyconstricted simple xylem-plate. The same process occurs in the supply of the ultimate pinnules from the pinna-traces.

Scales of three rows of parenchymatous cells, some six or eight in each row, occur on the leaves, usually above a vein or veinlet. Simple unicellular glands, but no multicellular hairs bearing glands, occur sporadically on rachis and leaves. Paleae of the type found in Peranema, but without glands on the edges, are present at the bases of the primary pinnae and on the raches and petiole in younger leaves; few or none are found on fullymatured leaves.

The sorus is at first entirely covered by the indusium. There is in this indusium no such pit or pore at one side as is found in that of Peranema. Here the indusium forms an unbroken symmetrical covering for the sporangia, coriaceous in texture, with cells of polygonal outline possessing triangular thickenings at the corners. In section these cells are rectangular, often square, with thickened walls.

The receptacle is short but not flattened, and is supplied by a short fan of tracheides from the vascular bundle of the veinlet on which the sorus is seated. The sporangia are numerous. They are of all ages in the same sorus and are inserted on the receptacle in distinctly mixed fashion. There is no trace of a basipetal sequence of development. The full developmental stages have unfortunately been unavailable, but even in moderately young sori no traces of very young sporangia were found at the basal edges of the 
receptacle. The youngest sporangia, showing merely two or three segmentation-walls, were found at the apex of the receptacle close to fully developed sporangia. There are apparently 95 sporangia in each sorus. Three countings gave $93,95,97$ for different sori.

The sporangium has a long stalk, scarcely so long as that of the sporangium of Peranema, with three rows of cells in the stalk. The annulus stops short of the stalk in its insertion (Fig. 22), but in passing across the head of the sporangium it twists slightly to one side and then back again into the vertical position before reaching the region of the stomium. This very slight obliquity of the annulus makes it possible to discriminate between the two sides of the sporangium, a fact referred to by Professor Bower ('Phil. Trans.', vol. cxcii, p. I04): 'In Diacalpe the two sides are so far dissimilar that it is possible still to distinguish the "central" from the ".peripheral" face."

Hairs are sometimes present on the stalks of the sporangia in Diacalpe (Fig. 23) as they are in Nephrodium filix-mas.

The spores in a single sporangium number about forty-eight. Each has an exospore and a perispore, attached at certain ring-shaped areas to the exospore and forming irregular folds and papillae on the surface of the spore. Here the circular pits with papillae in their centres are few in number; the main portion of the perispore is thrown into irregular folds, causing its projection into a series of warty protuberances (Fig. 22). The spores of Diacalpe are characteristic 'aspidioid' spores (Hannig, '11) and quite closely resemble those of Nephrodium filix-mas, where there are only warty protuberances on the surface of the spore. In Peranema the flanges of perispore are more prominent and numerous than the papillae; in - Diacalpe these flanges are almost entirely absent.

The prothallus has been described by Schlumberger (' Flora', cii, N. F. 2, pp. $3^{84}$ sqq.). On the under surface of the developed prothallus multicellular stalked glandular hairs are present. The stalk is composed of two or three cells, the middle one often showing a longitudinal division. The presence of multicellular hairs is a characteristic of the prothalli of the Cyatheaceae (Heim, 'Flora', 1xxxii, I896, pp. 360 sqq.). Schlumberger remarks for Diacalpe (p. $3^{85}$ ) that 'in many cases, where the terminal cells are not developed as glands, these structures cannot be distinguished from the multicellular hairs of the Cyatheaceae'.

The antheridium of Diacalpe has a segmented lid-cell, another characteristic feature of the Cyatheaceae (Bauke, 'Jahrb. fuir wiss. Bot.', x, p. 72). It is therefore unmistakable that the closest relationship exists between the prothallus of Diacalpe and that characteristic of the Cyatheaceae.

An attempt may now be made to compare the features of Peranema and Diacalpe with those of other Ferns, with a view to locating these genera. 
in a systematic position among the Filicales. They have so many characters in common that it will be quite possible to consider their position first together, and then to see how far the characters in which they differ may indicate special affinities for each of them with other Ferns which they resemble.

The ascending or upright stock which they show is shared by representatives of various groups of Ferns and cannot in itself be held as a strong diagnostic feature. It may none the less be noted that in Athyritum filixfoemina and in Nephrodium filix-mas the stocks are upright and of a similar type to that described for Peranema and Diacalpe. But in the latter pair there is a great development of sclerenchyma, which recalls the condition in the Cyatheaceae rather than that usual among the Polypodiaceae. In Athyrium and Neplirodium filix-mas definite sclerenchymatous sheaths are absent from the stocks.

The presence of both hairs and scales removes the two from such forms as those included in the (I) Eudryopteris section of Dryopteris (Christensen, '11) and relates them to (4) Lastrea.

In both cases the form of the leaf strongly suggests affinity with the Aspidieae. The tripinnate form is characteristic of the leaf in Nephrodium (Lastrea). The open, simply forked venation is a primitive feature, but it is shared by the members of the Eudryopteris section of Nephrodium and by numerous other members of the Polypodiaceae.

The hairiness of the leaves suggests a relatively primitive state, while the glands in the case of Peranema show resemblances both to those in Eudryopteris and in Lastrea.

When we look at the anatomical features we find that the general plan of the vascular system, with its advanced dictyostele, which shows no perforations but only leaf-gaps, and its subdivided leaf-trace, at once suggests affinity with Nephrodium filix-mas. The latter Fern appears, however, in the method of insertion of the leaf-trace strands on the gaps of the dictyostele to show an advance on the condition found in Peranema and Diacalpe. In these Ferns the leaf-trace bundles are inserted altogether on the lower half of the leaf-gap; in Nephrodium filix-mas the bundles are more spread over the sides of the gap. As in both cases the median main bundle of the leaf-trace is inserted at the lower fork of the limbs surrounding the gap, it would seem that this condition has been derived from that seen in solenostelic and in the simpler dictyostelic types by a breaking-up of the continuous horseshoe-shaped leaf-trace into a series of separate strands. The histology of the bundles would seem to confirm this. For the adaxial face of the leaf-trace in various Ferns, as illustrated in such types as Loxsoma (Gwynne-Vaughan, '0l, Figs. 5, 6, 7) and Davallia Speluncae (Gwynne-Vaughan, '03, Fig. 26), shows incurved edges. And the adaxial leaf-trace bundles in Peranema, Diacalpe, and Nephrodium filix-mas also show such incurved edges. Protoxylem groups appear in these 
curved edges of the leaf-trace in Loxsoma and Davallia. The adaxial strands of the leaf-trace in Peranema and Diacalpe each possess two protoxylem groups in the hooked portion of the strand (Fig. 6). The facts in Onoclea have an interesting bearing on this point. Thus in Onoclea orientalis the leaf-trace bundles at their insertion on the leaf-gap are two separate strands with hooks at each end. They are inserted just at the base of the gap and symmetrically on its limbs (Fig. 4, v). At a point higher up in the petiole, however, and before the departure of the pinnatraces, this pair of bundles becomes joined together and forms a single curved trace with hooked ends, from which the supply to the pinnae is given off in extramarginal fashion. The same condition is found in Onoclea sensibilis. ${ }^{1}$

I find in my specimens of Lomaria Spicant (Fig. 4, IV) that three bundles enter the dictyostele at the base of the leaf-gap, one in a median position, the other two in adaxial positions. ${ }^{2}$ The two adaxial bundles have hooked ends. The median one has a slightly curved plate of xylem, rather constricted in the centre and suggesting that it has been derived from the back of a triangular bundle of the type of Gleichenia dicarpa (Bower, 'Land Flora', p. 563, Fig. 314) through a suppression on either side of the central part of the limbs of the horseshoe.

Lastrea Oreopteris (Duval-Jouve, PI. I, Fig. 2), another dictyostelic type, has a couple of strap-shaped leaf-trace bundles, which are inserted on either side of the leaf-gap, almost midway up the gap. In this case also the two widen and ultimately fuse to form a single curved strand in the petiole below the first pair of pinnae.

In Athyrium filix-foemina (Fig. 4, vI), on the other hand, the leaftrace supply goes off from the base of the gap as a single triangular strand which almost at once breaks up into two strap-shaped bundles; and these below the first pair of pinnae fuse again into a single curved strand (DuvalJouve, Pl. I, Fig. I), a case recalling that of Plagiogyria semicordata (Bower, '10, p. 43I), in which a single curved strand breaks up into three parts, to reunite below the first pair of pinnae into a single strand.

These facts would seem to indicate that the broken leaf-trace has originated from a single horseshoe-shaped or curved strand by a suppres-

1 In Annals of Botany, IgII, p. 177, Sinnott considers the Onoclean double leaf-trace as an advance on the 'ancestral triangular mesarch bandle'-e.g. of Gleichenia Speluncae-and the approximation of the two bundles as a movement towards the ancestral type. But the two bundles do come together in the petiole before the pinnae go off, and so make his 'ancestral character'. Still (p. 167) the bese of the leaf-trace is 'the seat of ancestral characters'; ' here we should expect to find indications of what was the primitive foliar bundle in the ferns'; 'in this portion the effect of changing external conditions . . . must be felt last and least.' And yet the base of the leaf-trace in Onoclea sensibilis really shows an advanced condition (according to Sinnott's own hypothesis) on what appears higher up !

- This corresponds in sabstance, though not in exact detail, with the statement of Luerssen in Rab., Krypt.-Flora, vol. iii, p. I I4. 
sion of part of its xylem, or by its breaking up into a series of isolated strands, just as the leaf-trace of Dicksonia Barometz breaks up into a series of strands arranged in horseshoe fashion in the petiole (Gwynne-Vaughan, '03, Fig. 17). In some cases (e.g. Onoclea and Lastrea) the abaxial face has been suppressed, but later on resumes its position. In other cases short portions of the sides have been dropped out, causing a trace of several strands to result. These would seem at first, as in the type of Lomaria Spicant, to have been inserted right at the base of the gap. Later they became extended up its sides but kept to its lower half, as in the Peranema and Diacalpe type; while ultimately they became distributed well over the sides of the gap, extending into the upper half as well as occupying the lower, as in Nephrodium filix-mas. It is curious that no case has been found in which the several leaf-trace bundles, such as occur in Nephrodium filix-mas, fuse together in the petiole to form the single strand, while in cases with the Onoclean leaf-trace the single strand is regularly found in the petiole below the first pair of pinnae. But it would seem probable, at least, that development has gone along a line of breaking-up of the single horseshoe-shaped strand into several parts (Tansley, '08, p. I20), of the retention of these at first towards the base of the leaf-gap, and later of their extension up the arms of the gap. It would appear on this view that Peranema and Diacalpe come structurally very close to Nephrodium filixmas, but that they show scarcely so advanced a condition of the arrangement of the leaf-trace bundles on the dictyostele as does that Fern.

The discussion of the relationship of the pinna-traces to one another in different groups of Ferns must be left for a future paper. ${ }^{1}$ It will suffice to say at present that, while Peranema, Diacalpe, and Nephrodium filix-mas show exactly the same type of pinna-supply, the criterion of marginal or extramarginal departure of the supply cannot be held as valuable among the different groups. That there is some constancy in the type of pinnasupply in Ferns of the same group has been shown by P. Bertrand (09) and Gordon ('11) for Clepsydropsis, Diplolabis Römeri, and Metaclepsydropsis duplex. The vascular details in the leaves in Peranema, Diacalpe, and Nephroditsm filix-mas are, however, identical. Such a fact may have some weight in confirming an affinity of Peranema and Diacalpe with Nephrodium.

The presence of glands and of stalked hairs bearing glands would seem to indicate a relationship for Peranema with Lastrea. Glands are present internally in the rhizome and at the base of the petiole in Nephrodium filix-n:as (Sachs, p. 439 ; de Bary, pp. 89 and 220), internally at the base of the petiole in Aspidium spinulosum (de Bary, p. 220), externally on petiole

\footnotetext{
1 The question has already been discussed for the Osmundaceae by Sinnott ('10) and GwynneVaughan ('11).
} 
and rachis in Dryopteris pulvinulifera, (Bedd.) O. Ktze., ${ }^{1}$ on the leaf of $N$. molle (de Bary, p. 89), and in N. Sieboldii (Goebeler, '86).

The fertile leaf and sorus in both Peranema and Diacalpe at once suggest relationships with Cyatheaceae and Polypodiaceae. In both the insertion of the sorus is superficial. The sorus is restricted to the veinlet and is inserted at a point short of its termination. This also holds for Cystopteris, for the Aspidieae, and for Woodsia obtusa.

The indusium is characteristically basal in the Cyatheaceae and in the Woodsiinae (Diels) group of Polypodiaceae. The indusium of Diacalpe corresponds in insertion exactly with that of Woodsia. In the case of Peranema the indusium appears to be unequally developed on the two sides, giving a suggestion of a Cyatheaceous sorus twisted to one side and with its rim tucked in beside the point of insertion (cf. Allantodia, which is to Asplenium as Peranema is to Cyathea).

But in the Cyatheaceae the sorus is distinctly of the Gradate type (Bower, 'Studies', IV, p. 54). In Peranema and Diacalpe the sorus is clearly a mixed one, though suggestions of a basipetal tendency in development have been found in Peranema, a fact confirmed by the presence of a distinctly elongated receptacle and a spore-output per sporangium of sixty-four. In Diacalpe, where the relationship on the ground of insertion of the indusium appears clearly to be with the Cyatheaceae, the sorus is a characteristically mixed one, with no signs of any basipetal tendency. It must be regretted, however, that developmental stages have been unavailable. In the absence of these, final conclusions cannot be drawn with regard to the sorus of these two Ferns.

The texture of the indusium and its insertion suggests unmistakable affinities with Woodsia and Hypoderris, in which (e. g. Woodsia obtusa) the sorus at maturity bears an exceedingly close resemblance to that of Diacalpe.

The stalked sorus of Peranema is almost unique, though it does find a parallel in the stalked sorus of Marattia Kaulfussii. But in the latter the details are quite distinct, while in its stalk there is no vascular bundle developed. A mixed sorus is found throughout the genus Nephrodium. Sections through the sorus of $N$. molle and $N$. Sieboldii show very close resemblances to the sorus of Diacalpe. The receptacle in Dryopteris pulvinulifera, which in habit closely resembles Peranema, is a little larger than that of Diacalpe. It is shortly stalked and is supplied by tracheides from the vascular bundle of the vein on which it is inserted. The sporangium is long-stalked, with three series of cells in the stalk. The annulus stops short of the insertion of the stalk. It generally passes vertically across the capsule, but occasionally it may take a slightly oblique course, twisting

1 For the identification of this Fern (sent from India through the kindness of the Director of the Calcutta Botanic Garden) I am indebted to Dr. Carl Christensen.

T 2 
a little to one side at its point of maximum curvature and then twisting back into the vertical position. This recalls the condition of Diacalpe, in which, though the annulus stops short of the stalk, it is so far twisted in its course that the two faces of the sporangium can be readily distinguished.

Peranema has an oblique annulus, which always passes the insertion of the stalk, though it is not always indurated throughout its whole length. The presence of an oblique annulus in a Fern with a mixed sorus is only paralleled by the cases of Dipteris conjugata (Miss Armour, '07) and Plagiogyria (Bower, '10). In Peranema, however, the obliquity is very slight and is accompanied by unmistakable vestiges of a Gradate condition. In the absence of developmental evidence it would seem that Peranema occupies sorally an intermediate position between the Gradatae and the Mixtae, combining the receptacle, the annulus, and the spore-output of the one with the sporangial succession of the other. Diacalpe is more distinctly related to the Mixtae, in receptacle, sporangial succession, and sporeoutput. The annulus, while vertical in insertion, still possesses a tendency to obliquity, which is seen, less highly developed, in the annulus of Dryopteris pulvinulifera. This affinity with Nephrodium is strengthened by the presence of hairs on the sporangial stalks in Diacalpe and in Nephrodium filix-mas.

The spores in Peranema and Diacalpe are distinctly 'aspidioid'. But those of Diacalpe are more closely related to those of Nephrodium filix-mas than are those of Peranema. In Diacalpe warty protuberances are much more numerous than perispore flanges and papillate pitted areas. The spores of Dryopteris pulvinulifera occupy an intermediate position between those of Diacalpe and those of Peranema. They possess both warty protuberances and perispore flanges, but the warts are rather more numerous than the flanges.

The characters of the gametophyte generation are only known for Diacalpe, but they make its affinity with the Cyatheaceae quite undoubted.

On the whole, then, Peranema and Diacalpe occupy an intermediate position between the Cyatheaceae and certain phyla of Polypodiaceous character. With the former they are joined on the characters of the prothallus of Diacalpe and of the receptacle and annulus of Peranema; with the latter they show affinity in the vascular anatomy, the sporangial succession in the sorus, the length of the sporangial stalks, and the characters of the spores.

The affinity with the Aspidieae, and more particularly with the genus Nephrodium, which is suggested by their habit, has been confirmed in their dictyostelic vascular system, in the scales on petioles and raches, in the glands on leaves and leaf-stalks, in the mixed sequence of sporangia, in the hairs on the sporangial stalks in Diacalpe, and in the spore-markings in both Ferns.

The natural position for Peranema and Diacalpe seems to be with 
Woodsia and Hypoderris. The texture and insertion of the indusium are similar in all the four genera, while they all occupy an undoubtedly intermediate position between the Cyatheaceae and certain phyla of the Polypodiaceae.

It would seem that the very different habit of Woodsia on the one hand, and of Peranema and Diacalpe on the other, can be readily accounted for on the ground of environment, while the same remark applies to Hypoderris. Hypoderris has probably developed its hardly divided leaf in relation to conditions of shade. Peranema and Diacalpe, both inhabitants of mountainous tropical forest, have grown luxuriantly, while Woodsia, an essentially Alpine Fern, has reduced its vegetative system and elaborated the protective coverings of its indusium in a series of highly efficient scales.

Peranema and Diacalpe are undoubtedly very closely related to each other. It is hardly possible to say which is the more primitive, which the more advanced. The receptacle, sporangial succession, and annulus of Peranema are more nearly related to those of the Cyatheaceae than are those of Diacalpe. On the other hand, Diacalpe shows an undoubtedly Cyatheaceous prothallus. The spore-markings in Diacalpe most closely resemble those of Nephrodium filix-mas; those of Peranema are most nearly related to those of Dryopteris pulvinulifera. The presence of hairs on the stalks of the sporangia is common to both Diacalpe and Nephroditum filix-mas.

It would therefore seem probable that Peranema and Diacalpe fall naturally into the Woodsieae-Woodsiinae group of Polypodiaceae, and that this group occupies an intermediate position between the Cyatheaceae and certain other families of Polypodiaceae. There is very little doubt that both genera are closely related to the genus Nephrodium. It seems probable, then, that the Aspidieae sprang from a Gradate drift, of which the Cyatheaceae are near living representatives, and that Peranema and Diacalpe are related to that drift as relatively early examples. These indications make it seem probable that the mixed condition of the sorus of Nephrodium has arisen from a Gradate condition. This position traces one of the polyphyletic lines of the Polypodiaceae to the Cyatheaceae, and establishes a probably parallel series to that shown from Denustaedtia to Davallia and its derivatives.

\section{SUMMARY.}

I. Peranema cyatheoides, D. Don., has an advanced dictyostele without any perforations; its leaf-trace is inserted on the lower half of the leaf-gap; the pinna-supply is ' extramarginal' to all but the ultimate pinnae, to which it is 'marginal'; the sorus, which is borne on a short stalk, is a mixed_one; it has a Gradate receptacle, with traces remaining of a basipetal sequence of sporangia; the annulus is slightly oblique; the spores are 'aspidioid'.

2. Diacalpe aspidioides, Bl., coincides with Peranema in the details 
of its vascular anatomy; the sorus is a mixed one, with no traces of an earlier basipetal sequence ; the annulus is vertical in insertion, but slightly twisted in its course across the sporangial head; the spores are markedly 'aspidioid'; the prothallus is Cyatheaceous.

3. Both Ferns show relationships with the members of the genus Nephrodium, particularly with Nephrodium filix-mas, Rich., in vascular anatomy, the character of glands on the leaves, the sporangial stalks, and the spore-markings.

4.. Peranema and Diacalpe are most nearly related to Woodsia and Hypoderris, and fall naturally into the Woodsieae-Woodsiinae group of Polypodiaceae, which is intermediate between the Cyatheaceae and the Aspidieae.

5. It seems probable that the Aspidieae sprang from a Gradate ancestry, and that Peranema and Diacalpe are relatively early members of a phyletic drift to the Polypodiaceae, of which the Cyatheaceae are near living representatives.

\section{BibLIOgRAPHY.}

Armour, H. M. ('07): On the Sorus of Dipreris. New Phytologist, 1907, pp. $238,244$.

BAuke, H. ('76): Entwickelangsgeschichte des Prothallioms bei den Cyatheaceen, verglichen mit derselben bel den anderen Farnkriatern. Jahrb. f. wiss, Bot, x, p. 49.

Brddoue, R. H. (63) : The Ferns of Southern India, pp. 25, 85.

Bertrand, C. Eg., et Cornaille, F. (02) : Etude sur quelques caractéristiques de la structure des Filicintes actuelles.

Bertrand, Paul ('09): Études sur la fronde des Zygoptéridées, p. ia7.

Blums, C. L. ('28) : Enameratio Plantarum Jarae et Insularum adjacentium.

Bower, F. O. (98): Studies in the Morphology of Spore-prodacing Members. IV. Phil. Trans, B. crcii, pp. $55-60,104$. (08): The Origin of a Land Flora, pp. 610,617.

('10): Stadies in the Phylogeny of the Filicales. I : Plagiogyria. Annals of Botany, xxiv, p. 423 .

Brown, Robert ('67): Miscellaneous Works. Ray Society, ii, pp. 546-7.

Christ, H. ('97) : Die Fankriuter der Erde, p. 286.

('08): Einige Bemerkungen tu dem Index Filicum von C. Christensen. Hedwigia, rlvii, p. 145 .

Christensen, C. ('06) : Inder Filicum.

('11): On a Natural Clasuification of the Species of Dryopteris. Sertryk af Biologiske Arbejder, p. 75.

Clarke, C. B, ('80) : Review of the Fems of Northern India. Trans. Linn. Soc., and ser., 1, p. 435. DE BAry, A. ('84) : Comparative Anatomy of the Vegetative Organs of the Phanerogams and Ferns. Engl. ed., pp. $89,220,343$.

Diels, L. (02) : In Engler and Prantl's Natürliche Pfanzenfamilien, 1, 4, pp. 159, I60.

DON, David ('25) : Prodromas Florae Nepalensis, p. I 2.

Doval-Jouve, J. ('56-61) : Études sur le pétiole des Fongèré. Hapuenau.

Gardiner, W., and ITO, T. ('87): On the Structure of Mucilage-secreting Cells of Blechntum accidentale and Osmeunda regalis. Annals of Botany, 1, p. 27. 
Goebeler, E. ('86) : Die Schatrvorrichtangen am Stammscheitel der Farne. Flora, 1886, pp. 451, 476,483 .

Gordon, W. T. ('11): On the Structure and Affinities of Diplolabis Römeri (Solms). Trans. Roy. Soc. Edin., xlvii, pt. iv, p. 7 I I.

(11) : On the Structure and Affinities of Metaclepsydropsis duplex (Williamson). Trans. Roy. Soc. Edin., xlviii, pt. i, p. $16_{3}$.

Gwynne-Vaughan, D. T. ('01) : Observations on the Anatomy of Solenostelic Ferns. I : Loxsoma. Annals of Botany, xv, p. 7 I.

(03): Observations on the Anatomy of Solenostelic Ferns, Part II. Annals of Botany, xvii, p. 68 .

Botany, xxv, p. $5^{2} 5$.

('11): Some Remarks on the Anatomy of the Osmundaceac. Annals of and Kidston, R. (08): On the Origin of the Adaxially-curved Leaftrace in the Filicales. Proc. Roy. Soc. Edin., rxvii, p. 433.

Hannig, E. ('11): Ueber das Vorkommen von Perisporien bei den Filicineen, nebst Bemerknngen über die systematische Bedeutung derselben. Flora, N. F., iii, p. 32I.

Heim, C. ('98) : Untersuchangen iber Farmprothallien. Flora, lrxii, p. 329.

Hooker, W. J. ('46): Species Filicam.

— Genera Fllicum. Tab. XXI, XCIX.

and BAKKR, J. G. ('74): Synopsis Filicam.

Kunze, G, ('37) : Analecta Pteridographica.

Lachmann, Paul ('84): Recherches sur le système liberolignenx des Fougéres. Lyons.

LotsY, J. P. ('09): Vorträge uber Botanische Stammesgeschichte. II, p. 33.

Mettenius, G. ('56) : Filices Horti Botanici Lipsiensis.

Presl, C. B. ('86) : Tentamen Pteridographiae, pp. 65, 245.

Raciborski, M. ('98) : Die Pteridophyten der Flora von Buitenzorg.

SAchs, J. (82): Text-book of Botany, and Eng. ed.

Sснаснт, H. ('63) : Ueber ein neues Secretions-Organ im Wurzelstock von Nephrodium filix-mas. Jahrb. f. wiss. Bot., iii, p. 353 .

Schlumberger, O. ('11): Familienmerkmale der Cyatheaceen und Polypodiaceen and die Beziehungen der Gattung Woodsia and verwandter Arten $z$ beiden Familien. Flora, N. F., ii, Heft 4 , pp. 383-414

Sinnott, E. W. ('10) : Foliar Gaps in the Osmundaceae. Annals of Botany, xxiv, p. Jog.

('11): The Evolution of the Filicinean Leaf-trace. Annals of Botany, xxv, p. 167.

Sмiтн, J. ('42) : Genera of Ferns. Houker's Journal of Botany, iv, p. Igo.

TAnsley, A. G. ('08) : Lectares on the Evolation of the Filicinean Vascular System.

Thomae, K. ('86): Die Blattstiele der Farne. Jahrb. f. wiss. Bot., Ivii, pp. 136,140 sqq.

Wall.ich, N. ('80): Plantae Asiaticae Rarae, p. 4 I.

\section{DESCRIPTION OF PLATES XXVIII AND XXIX.}

\section{Illustrating Mr. Davie's paper on Peranemaa and Diacalpe.}

Figs, 1-3, 5-21, are of Peranema cyatheoides.

Figs, 22 and 23 are of Diacalpe aspidioides.

Figs, 1, 2, 3, and 7 are freehand drawings. Fig. 4 is a diagrammatic representation of leaf-gaps and the subtending leaf-traces in various dictyosteles. Figs. 5,6,8-23 have been drawn with the aid of a camera lucida.

Fig. I. Pinna of Peranema, showing open, simply forked venation. The veinlets terminate at points short of the margin. $\times 3$.

Fig. 2. Transverse section of stock, showing the dictyostelic arrangement of the meristeles (st.), the leaf-trace bundles $(u$.$) , and the very numerous sclerotic patches (sp.). \times 4$. 


\section{Davie.-Structure and Affinities of Peranema and Diacalpe.}

Fig. 3. Soccessive sections through the petiole, showing the departure of the rascular supply to the basal pinnae. ad., adaxial strands ; m., median main strand; ss., subsidiary strands; $c c$. ., commissural strands; $p p$., pinne-trace strands. $\times 8$.

Fig. 4 Series of diagrams illustrating the insertion of the leaf-trace bundles on the dictyostele in various Ferns. I. Peranema cyatheoides. Portion of dictyostele seen from within, showing leafgap and the bundles from the leaf subtending this gap. Ir. The same leaf-gap viewed from without. m2., median main leaf-trace strand; ad., adaxial main strands. III. Another leaf-gap with the bundles

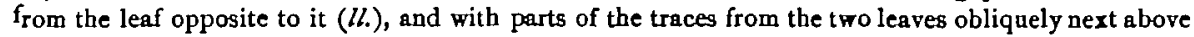
$(a a)$ and $(b b)$. Iv. Lomaria Spicant. Dictyostele at leaf-gap, with the three leaf-trace bundles. v. Onoclea orientalis. Dictyostele at leaf-gap, with the two leaf-trace bundles. vi. Athyrium filixfoemina. Dictyostele at leaf-gap, showing the insertion of the leaf-trace. It leares the dictyostele as an undivided trace and in the base of the petiole becomes divided into two strap-shaped strands. All considerably magnified.

Fig. 5. Trangverse section through the young shoot of Peramema, just below the aper, showing the first lignification in the stele. $\times 45^{\circ}$.

Fig. 6. Trangverse sections through the adaxial main strands of the leaf-trace, showing the 'extramarginal' type of supply to the basal pinna. All $\times 7^{6}$. (a) Strand below the level of the pinna, showing the hooked end, from which the supply goes off to the pinna. (b) Pinna-supply in process of being given off. (c) Reconstituted adaxial strand ( $a d)$ with pinna-trace $(p)$ passing out to the pinna.

Fig. 7. Successive transverse sections through the rachis of a basal pinna to show the development of the pinna-trace, from the point of departure from the petiolar adarial strand ( $I$ ) up to the fally constituted condition $(x I)$. All about $\times 8$.

Fig. 8. Palea from young leaf-stalk. $\times 3$.

Fig. 9. Hair from the rachis of the frond, showing glands on the carved portion. $\times 76$.

Fig. 10. Gland from the palea of a young frond. $\times 45^{\circ}$.

Fig. II. Glands from the surface of the mature petiole. $\times 450$.

Fig. 12. Transverse section through a young pinna, showing marginal segmentation of the usual Leptosporangiate type. $\times 45^{\circ}$.

Fig. 13. Longitadinal section through the stalked sorus, showing the elongated receptacle with its vascular supply and the mixed arrangement of the sporangia. $\times 76$.

Fig. 14. Longitudinal section through the sorus, showing the elongated receptacle and the mixed succession of sporangia. The indusium is two-layered at its base. $\times 7_{76}$.

Fig. 15. Longitudinal section throngh the sorns, showing the way in which the rim of the indusiam is tucked in on the lower side, close to the point of insertion of the stalk. $\times 76$. $\times 150$.

Fig. 16. Section through a mature sporangium, showing the slight obliquity of the annalus.

Fig. 17. Section through the stalk of a matare sporanginm. $\times 150$.

Fig. 18. Almost mature sporangium, showing the continuation of the cells of the annulus past the stalk. $\times 225$.

Fig. 19. Mature sporangium, showing the slightly oblique insertion of the annulus. $\times 15^{\circ}$.

Fig. 20. Sporangium, showing the indarated cells of the stomium. $\times$ I 50.

Fig. at. Spores of Peranema, showing the papillate pits formed by the perispore. $\times 45^{\circ}$.

Fig. 23. Section through a mature sporangium of Diacalpe, showing the insertion of the annulus and the markings on the spores. $\times 150$.

Fig. 23. Mature sporangium of Diacalpe aspidioides, showing a hair on the stalk. $\times 15^{0}$. 


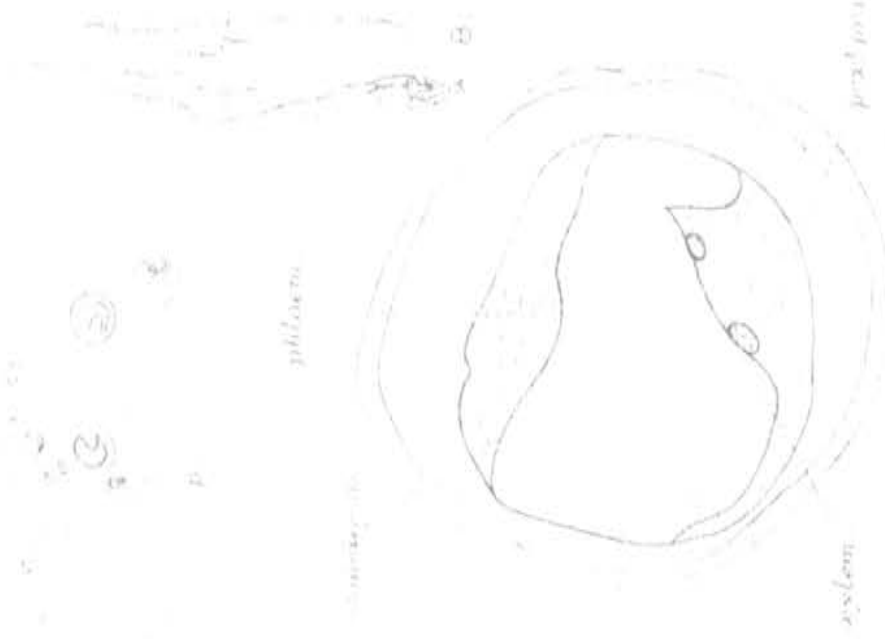

$\lim _{4}(x)$

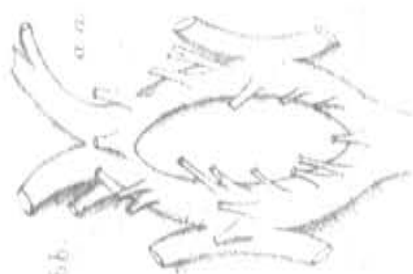

(a)

(ब) 5 (i)

$\left.-f_{0}\right)$

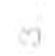
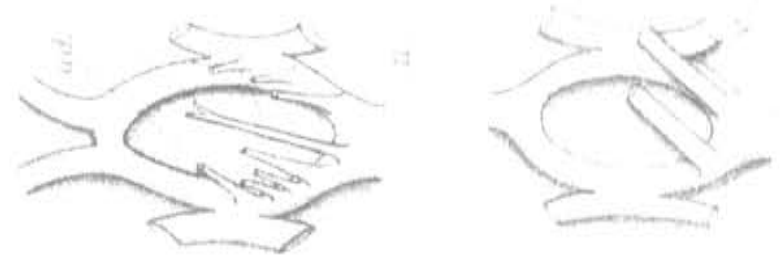

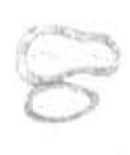

ses

$2(5)$
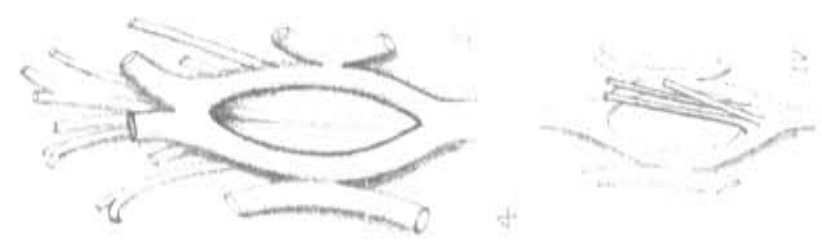

40

$(0)$<smiles>Cc1ccccc1</smiles><smiles>c1ccccc1</smiles><smiles>[c-]1ccccc1</smiles><smiles>c1ccccc1</smiles>

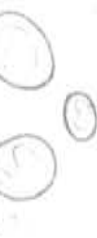

0

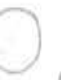<smiles>C1CCCCCCCCCCCCCCCC1</smiles><smiles></smiles>

(a)
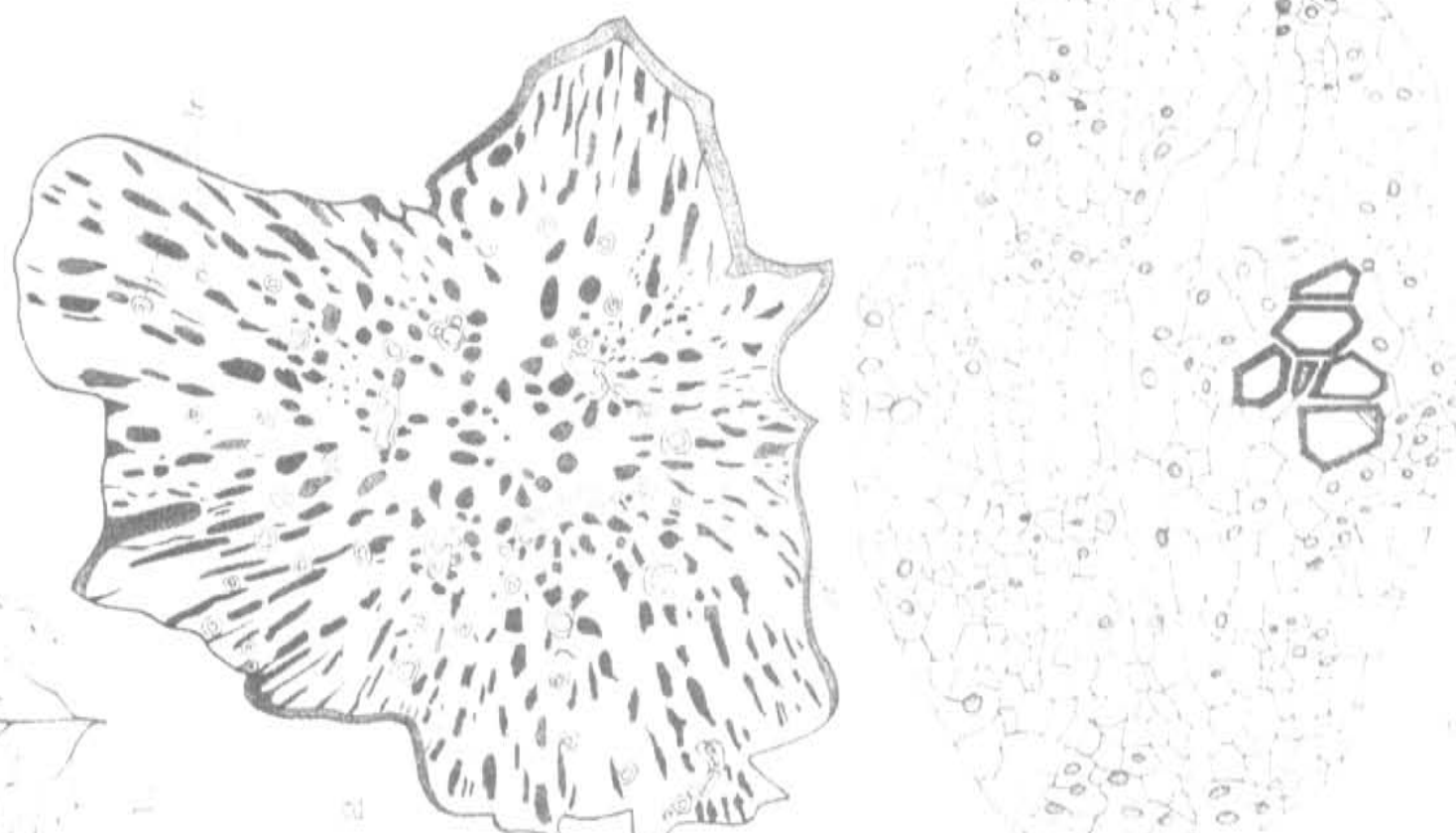

$\therefore \therefore$

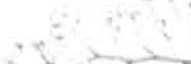
on 09 March 2018 


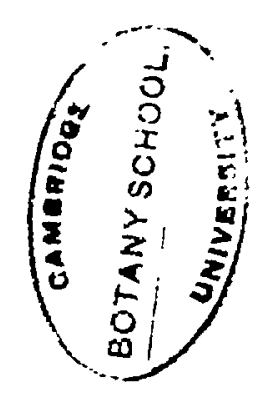




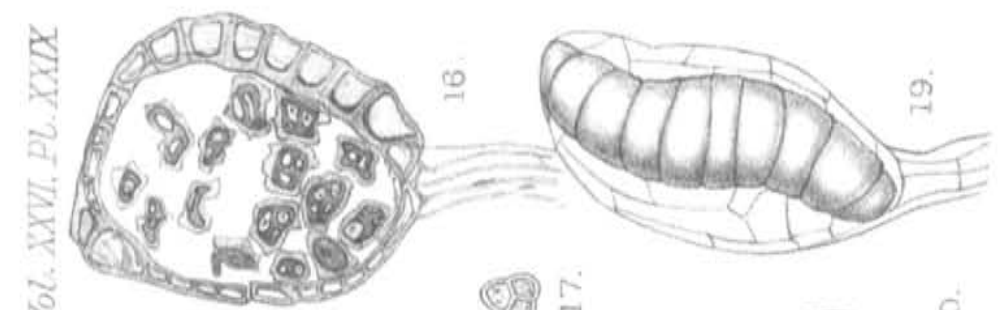

(69)

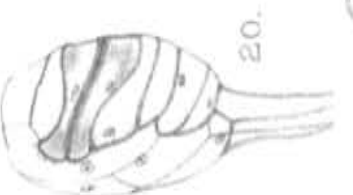

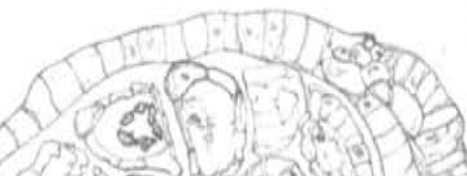

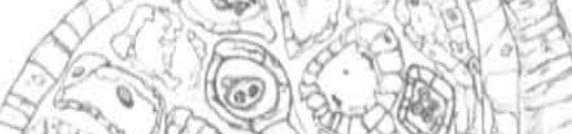
A 1400 a - 20.5050 A sis in.

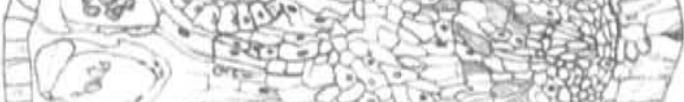

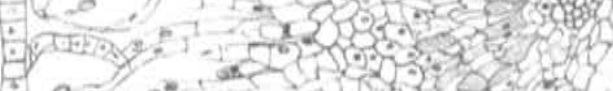
E - 0 (5) a
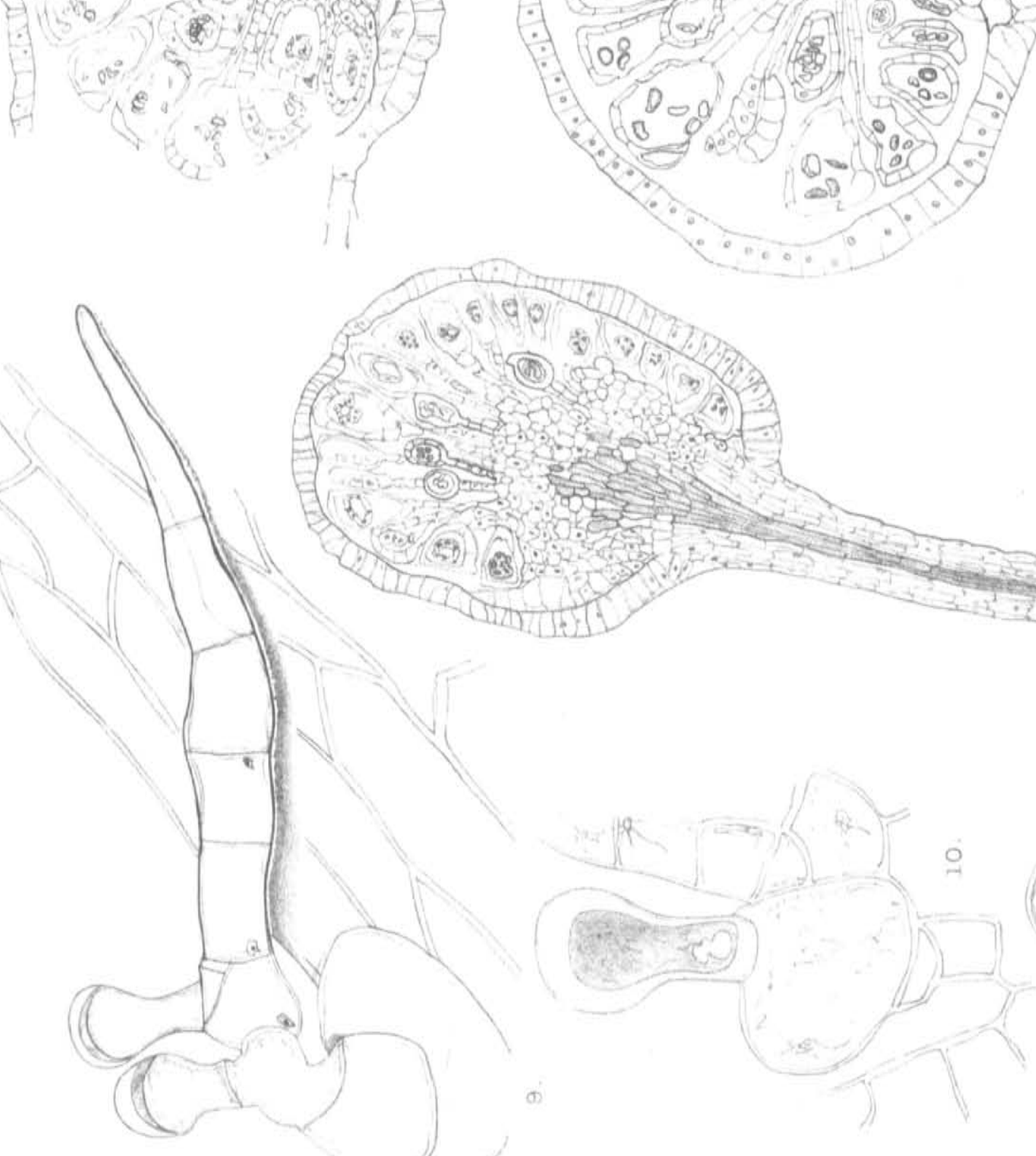

: 8 v $\therefore 08$

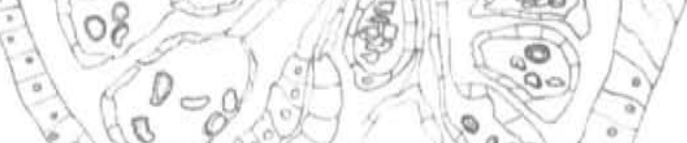

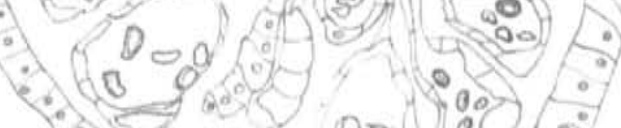

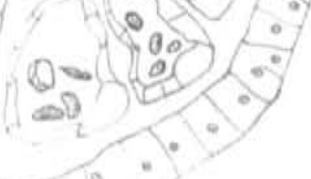

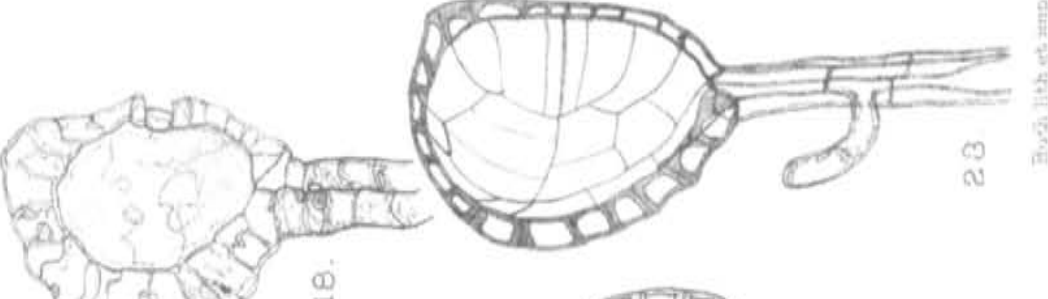
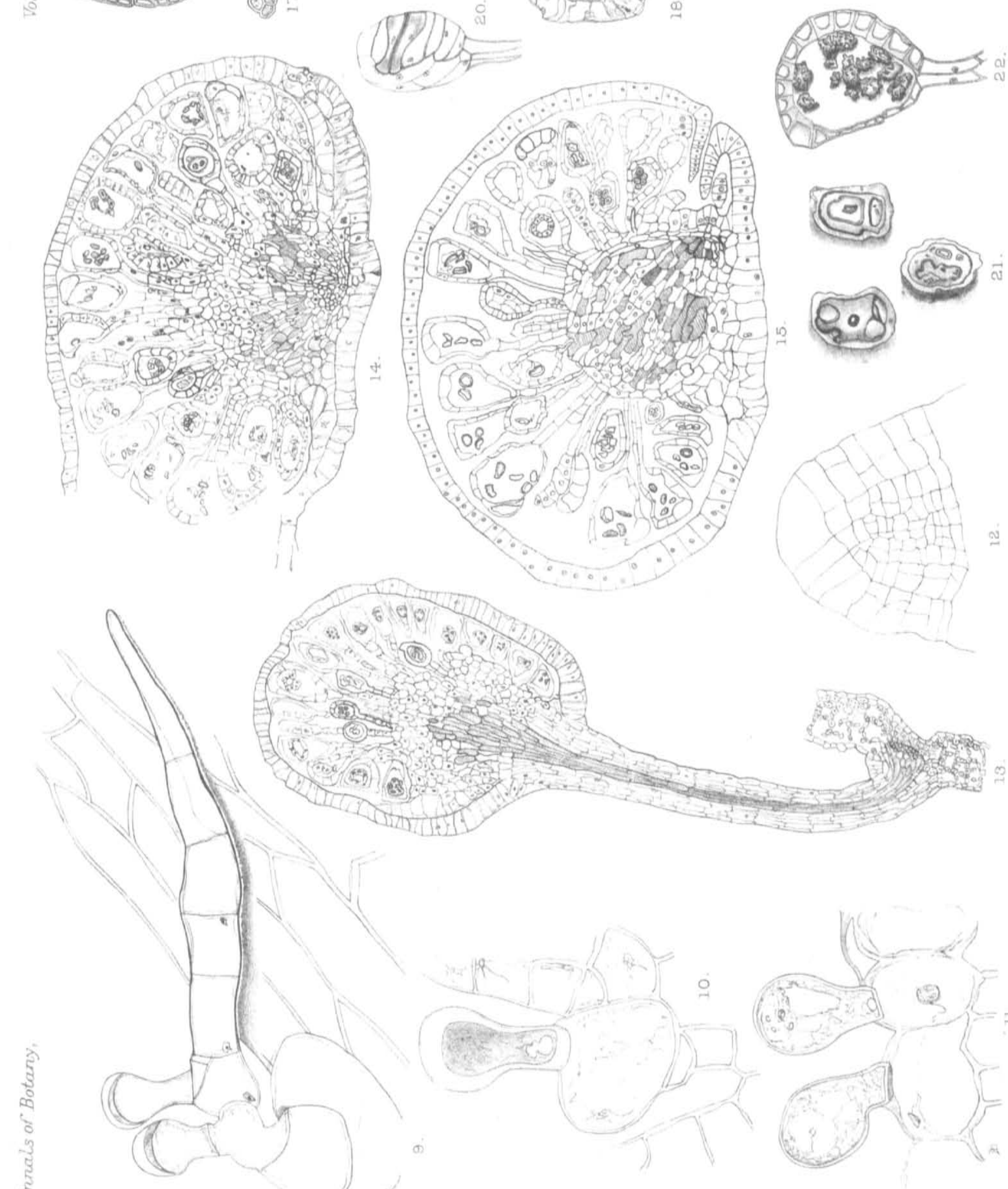
,

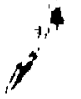

Downloaded from https://academic.oup.com/aob/article-abstract/os-26/2/245/235245

Downloaded from https://academic. oup.com/aob/article-abstract/os-26/2/245/235245
by University of California, Santa Barbara user by University of California, Santa Barbara user
on 09 March 2018 